\title{
Modeling of a braking process of a mine diesel locomotive in terms of different rail track conditions
}

\author{
Ihor Taran ${ }^{1 *}$, Anatolii Bondarenko ${ }^{2}$, Oleksii Novytskyi ${ }^{1}$, Zhemazhan Zhanbirov ${ }^{3}$, and Iryna \\ Klymenko $^{1}$ \\ ${ }^{1}$ Dnipro University of Technology, Department of Transportation Management, 19 Yavornytskoho \\ Ave., 49005 Dnipro, Ukraine \\ ${ }^{2}$ National Technical University "Kharkiv Polytechnic Institute”, 2 Kyrpychova St., 61002 Kharkiv, \\ Ukraine \\ ${ }^{3}$ Kazakh Academy of Transport and Communications named after M. Tynyshpaev, 97 Shevchenko \\ St., 050012 Almaty, Republic of Kazakhstan
}

\begin{abstract}
The paper considers braking process of mine diesel locomotive with hydrostatic mechanical transmission (HSMT) operating according to "input differential" scheme. Braking process is modeled in terms of kinematic motor disconnection from wheels under maximum possible braking moments on wheels. Showing up and systematizing of basic regularities concerning the distribution of power flows within closed transmission contour in the process of braking have been implemented with the help of software support developed by means of MatLab/Simulink. The simulation results of braking due to the hydrostatic transmission and the braking system during the movement of a diesel locomotive in the transport and tractive ranges are presented in the form of graphical dependences. It has been determined that when a kinematic disconnection of a mechanical branch takes place within the closed loop of HSMT No. 1 by means of a clutch, neither ascent/descent angle nor net tractive effort of mine diesel locomotive effect significantly the distribution of kinematic, power, and energy parameters of the HSMT.
\end{abstract}

\section{Introduction}

High requirements for the compliance with tight emission standards, and decrease in maintenance charges result in the necessity to solve more complex problems in the field of research intended to develop new solutions capable of improving overall transport efficiency $[1,2]$. In this context, possible progress is based upon the improved efficiency and reliability of transmissions exercising a significant influence on the operating factors of traction machines [3, 4]. For decades both world [5-7] and national [8-10] machinebuilding industries widely use hydrostatic mechanical transmissions (HSMTs) owing to their higher efficiency to compare with a hydrostatic drive and higher control flexibility to compare with purely mechanical transmission. The greatest HSMT advantage is its ability

\footnotetext{
* Corresponding author: taran7077@gmail.com
} 
to separate completely a motor from a wheel behavior helping the motor operates with the maximum efficiency and minimum waste gas emission.

Use of HSMTs for mine diesel locomotives [11], operating underground [12, 13], is especially topical issue since tight demands are placed on the compliance with environmental standards in mines $[14,15]$. However, the increased motion speeds of mine trains with diesel locomotives aggravate a problem of safety preservation in a braking mode. Analysis of a diesel locomotive motion in a braking mode should involve a number of factors through which modeling of a diesel locomotive differs greatly from similar calculations for other traction transport facilities [16, 17]. Currently, a problem of wheelrail adhesion [18], contacting in the presence of intervening medium, is the greatest issue in the context of mine conditions. Nonavailability of the formulated mathematical models and methods of theoretical determination of frictional characteristics of wheel and rail, not developed to quantitative evaluation, prevent from assessment of power consumption implemented to the braking effort by a transmission.

\section{State of question and statement of research problem}

HSMT is a hybrid transmission combining stepless speed characteristics of a traditional hydraulic transmission [19] and high performance of a mechanical power transmission [20]. Significant distinction of two-flow stepless HSMTs from the stepped mechanical transmissions and other transmission types is the fact that losses in hydrostatic drive (HSD) as well as its efficiency depend heavily upon operation mode of the transmission affecting the amount of power flows [21]. Power circulation within the two-flow transmissions puts forward a task to distribute the power flows along the closed HSMT circuits during the process of mine locomotive braking since it places restrictions on the structure of such a transmission and on its kinematics.

The early research concerning modeling of hydrostatic transmissions with continuous variable power represents nonlinear simulators describing a pump with the variable capacity and a fixed-volume motor taking into consideration leakage losses [22] as well as linear models for adaptive control concepts [23]. Subsequently [24], a nonlinear model of a transmission with loss models in the stationary state of the two machines (i.e. a pump with the variable capacity and a motor) has been developed to determine values of inlet transmission speed and a vehicle speed.

Paper [25] performs system modeling of hydromechanical transmissions and develops functional dynamic model of a transmission with the distribution of power flows for a tractor. Authors of [26] have designed and simulated hydrostatic variator with power distribution for high-capacity vehicles. Identification of the operational problems in the process of transmission dynamics has become the most interesting their finding.

Hydraulic hybrid system of Cumulo type for urban buses is the early example for road vehicles [27]. Especially for wheel loaders, authors of [28] represented a multimode hydrostatic mechanical transmission with power distribution which fuel economy potential is no less than $15 \%$ higher to compare with the available solution with a hydraulic converter. Authors of paper [29] have obtained similar findings.

To analyze a hydrostatic drive for road vehicles, authors of [30] applied constant parameters for linear coefficients and quadratic coefficients in terms of hydraulic flow and pressure loss respectively; authors of [31] developed an expression of the hydraulic unit flow as a function of input flow for a control servovalve and introduced pressure-dependent coefficient to assess flow leakage.

In the process of analysis of fuel consumption by urban buses, behaviour of hydraulic modules has been simulated while applying two loss coefficients for an ideal module. The 
coefficients were expressed in terms of polynomial functions of specific speed, pressure, load, and shift location [32].

Models of subsystems for each functional component of a hydrostatic transmission have been designed in [33] as a tool of a system modeling; moreover, they have been integrated into the unified system model with the use of MATLAB/Simulink which was confirmed experimentally while analyzing energy flow of a wheel loader ibid.

In addition, commercial software Amesim with the inbuilt transient analytical equations for hydraulic, pneumatic, thermal, electric, or mechanical systems is also popular to analyze transmissions as multiple domain systems $[32,34]$.

Papers [35-37] make a point it is expedient to use stepless two-flow HSMTs for heavy wheel vehicles and track-type vehicles while emphasizing advantages of the transmissions. Moreover, HSMT gives much better way to automation compared with the stepped mechanical transmissions, which improves labour conditions of an operator $[38,39]$.

While analyzing stepless two-flow HSMTs, it should be noted that they have proper design characteristics and may be manufactured according to following schemes: "input differential" (for instance, Vario); "output differential" (for instance, S-Matic); and with a variable structure (for instance, MALI WSG 500) [40].

\section{Data for study}

Papers [11, 41] propose prospective HSMTs with "input differential" and "output differential" designed for mine diesel locomotives with the declared $0.85-0.9$ maximum efficiency. A hydrostatic mechanical transmission, operating in terms of "input differential" scheme (Figs. 1 and 2) has been selected as an object of mechanical modeling of a mine diesel locomotive braking process if intervening medium is available.

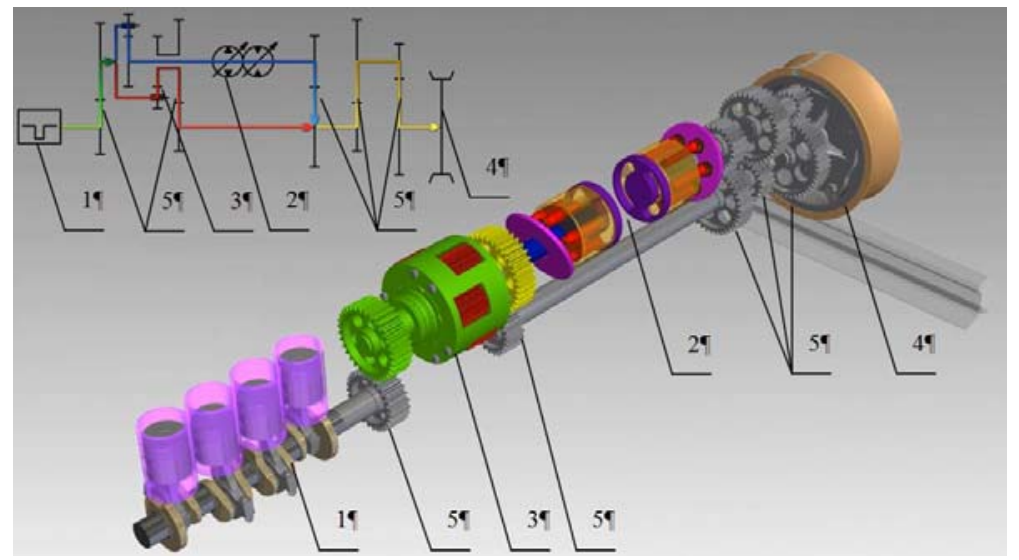

Fig. 1. 3-D model of HSMT No. 1: 1 - internal-combustion motor; 2 -hydrostatic drive; 3 - planetary reducing gear; 4 - wheel; 5 - reducing gears.

The paper uses a method of transmission analysis. The method relies on kinematic scheme breakdown into structural components as well as the development of a matrix system on the basis of generalized kinematic and power basic matrices of each component of the transmission [42].

Kinematic link indexing is performed randomly in such a way that each of the links has a proper value of angular speed. However, the moments are set with dual indexing; index one of a moment coincides with the number of kinematic link and index two is a Latin letter in line with the alphabet depending on the link complexity. Thus, each link involves no 
fewer than two moments: input moment and output one, for instance, $M_{2 a}$ and $M_{2 \mathrm{~b}}$ for kinematic link No. 2 associated with angular speed $\omega_{2}$.

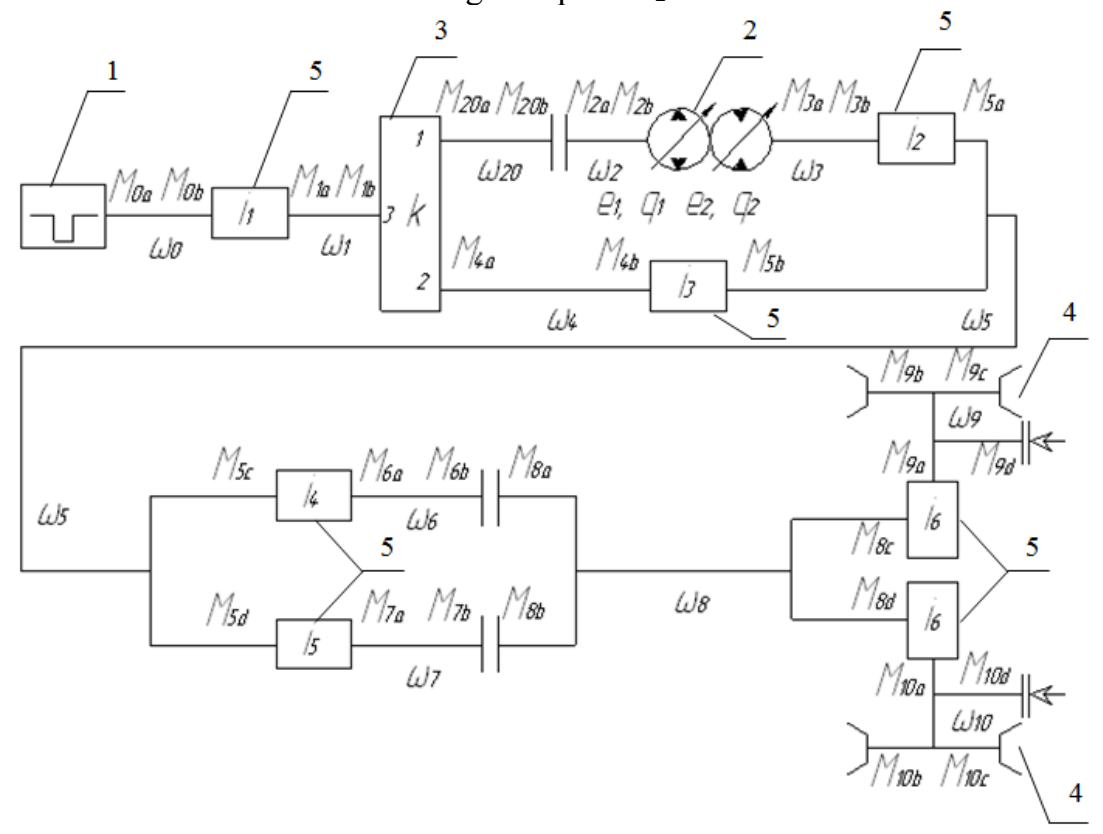

Fig. 2. Physical model of HSMT No. 1: $1-5$ correspond to Fig. 1; $\omega_{i}$-angular speed of transmission link; $i_{j}$ - transmission ratio; $k$-internal transmission ratio of planetary gear set; $M_{n m}$ - moments on HSMT links; $n$-indices corresponding to the number of link angular speed; $m$ - indexing letters corresponding to the moments of the ends of links; $e_{1}, e_{2}$ - parameters of HSD hydraulic machines control; $q_{1}, q_{2}$ - maximum capacities of hydraulic machines.

Approach to make a dynamic description of HSMT in a braking mode has been proposed by paper [36]; the approach is based upon the use of models described in papers $[43,44]$.

The mathematical model describing changes in power parameters, kinematic parameters, and energy parameters of HSMT No. 1 is presented in the form of the following equations $(1-5)$ :

Thus, equation one explains the transmission-motor relation as follows:

$$
\dot{\omega}_{0}=\dot{\omega}_{d}
$$

Loss moment within hydraulic machines is determined using the following expression:

$$
\begin{aligned}
& e_{1}(t) \cdot q_{1} \cdot \dot{\omega}_{2}+q_{1} \cdot \omega_{2} \cdot \dot{e}_{1}(t)-e_{2}(t) \cdot q_{2} \cdot \dot{\omega}_{3}-q_{2} \cdot \omega_{3} \cdot \dot{e}_{2}(t)= \\
& =\left(\frac{V_{0^{*}}}{2 \cdot \pi \cdot E\left(g^{*}\right)} \cdot\left(\left|\omega_{2}\right|+\left|\omega_{3}\right|\right)\right) \cdot \Delta \dot{P}+\frac{V_{0^{*}}}{2 \cdot \pi \cdot E\left(g^{*}\right)} \cdot\left(\frac{d}{d t}\left|\omega_{2}\right|+\frac{d}{d t}\left|\omega_{3}\right|\right) \cdot \Delta P+ \\
& +\gamma \cdot\left(\frac{K_{1 y}}{\mu} \cdot\left(1+C_{1 y} \cdot\left|\omega_{2}\right|\right)+\frac{K_{2 y}}{\mu} \cdot\left(1+C_{2 y} \cdot\left|\omega_{3}\right|\right)\right) \cdot \Delta \dot{P}+ \\
& +\gamma \cdot\left(\frac{K_{1 y}}{\mu} \cdot C_{1 y} \cdot \frac{d}{d t}\left|\omega_{2}\right|+2 \cdot \frac{K_{2 y}}{\mu} \cdot C_{2 y} \cdot \frac{d}{d t}\left|\omega_{3}\right|\right) \cdot \Delta P .
\end{aligned}
$$

Total loss of working liquid within hydraulic pumps and hydraulic motor is as follows: 


$$
\begin{aligned}
& M_{2 b}-e_{1} \cdot q_{1} \cdot \Delta P=-\Delta M_{1} \cdot \operatorname{sign}\left(\omega_{2}\right) ; \\
& \Delta M_{1}=q_{1} \cdot\left[\bar{K}_{1} \cdot\left|\omega_{2}\right| \cdot\left(1+\bar{K}_{2} \cdot \bar{e}_{1}^{2}\right)+\frac{\bar{K}_{5} \cdot\left(1+\bar{K}_{4} \cdot\left|\bar{e}_{1}\right|\right)}{\left(1+\bar{K}_{3} \cdot\left|\omega_{2}\right| \cdot D_{q 1}\right)} \cdot \Delta P+\frac{\bar{K}_{8} \cdot\left(1+\bar{K}_{7} \cdot\left|\bar{e}_{1}\right|\right)}{\left(1+\bar{K}_{6} \cdot\left|\omega_{2}\right| \cdot D_{q 1}\right)}\right] ; \\
& D_{q 1}=\sqrt[3]{2 \cdot \pi \cdot q_{1}} ; M_{3 a}+e_{2} \cdot q_{2} \cdot \Delta P=-\Delta M_{2} \cdot \operatorname{sign}\left(\omega_{3}\right) ; \\
& \Delta M_{2}=q_{2} \cdot\left[\bar{K}_{1} \cdot\left|\omega_{3}\right| \cdot\left(1+\bar{K}_{2} \cdot \bar{e}_{2}^{2}\right)+\frac{\bar{K}_{5} \cdot\left(1+\bar{K}_{4} \cdot\left|\bar{e}_{2}\right|\right)}{\left(1+\bar{K}_{3} \cdot\left|\omega_{3}\right| \cdot D_{q 2}\right)} \cdot \Delta P+\frac{\bar{K}_{8} \cdot\left(1+\bar{K}_{7} \cdot\left|\bar{e}_{2}\right|\right)}{\left(1+\bar{K}_{6} \cdot\left|\omega_{3}\right| \cdot D_{q 2}\right)}\right] ; \\
& D_{q 2}=\sqrt[3]{2 \cdot \pi \cdot q_{2}} .
\end{aligned}
$$

HSMT kinematics is explained with the help of a system of the following equations:

$$
\begin{aligned}
& \dot{\omega}_{0} \cdot \dot{i}_{1}-\dot{\omega}_{1}=0 ; \quad \dot{\omega}_{20}-k \cdot \dot{\omega}_{4}+(k-1) \cdot \dot{\omega}_{1}=0 ; \quad \dot{\omega}_{20}-\dot{\omega}_{2}=0, \Psi=1 ; \\
& \dot{\omega}_{3} \cdot i_{2}-\dot{\omega}_{5}=0 ; \quad \dot{\omega}_{4} \cdot i_{3}-\dot{\omega}_{5}=0 ; \quad \dot{\omega}_{5} \cdot i_{4}-\dot{\omega}_{6}=0 ; \quad \dot{\omega}_{5} \cdot i_{5}-\dot{\omega}_{7}=0 ; \\
& \dot{\omega}_{6}-\dot{\omega}_{8}=0, Y=1 ; \quad \dot{\omega}_{7}-\dot{\omega}_{8}=0, \quad Y=0 ; \\
& \dot{\omega}_{8} \cdot i_{6}-\omega_{9}=0 ; \quad \dot{\omega}_{8} \cdot i_{6}-\omega_{10}=0 .
\end{aligned}
$$

Power transmission parameters can be described using the following equations:

$$
\begin{aligned}
& M_{0 b} \cdot \eta_{1}^{\Theta \cdot \operatorname{sign}\left(N_{0 b}\right)}+i_{1} \cdot M_{1 a}=0 \\
& M_{20 a} \cdot \eta_{13}^{\Theta \cdot \operatorname{sign}\left(N_{20 a}\right)}+M_{4 a} \cdot \eta_{23}^{\Theta \cdot \operatorname{sign}\left(N_{4 a}\right)}+M_{1 b}=0 \\
& M_{20 a} \cdot k \cdot \eta_{13}^{\Theta \cdot \operatorname{sign}\left(N_{20 a}\right)}+M_{4 a} \cdot \eta_{23}^{\Theta \cdot \operatorname{sign}\left(N_{4 a}\right)}=0 ; M_{20 b}+M_{2 a}=0, \quad \Psi=1 ; \\
& M_{20 b}=M_{2 a}=0, \Psi=0 ; M_{3 b} \cdot \eta_{2}^{\Theta \cdot \operatorname{sign}\left(N_{3 b}\right)}+i_{2} \cdot M_{5 a}=0 ; \\
& M_{4 b} \cdot \eta_{3}^{\Theta \cdot \operatorname{sign}\left(N_{4 b}\right)}+i_{3} \cdot M_{5 b}=0 \\
& M_{5 c} \cdot \eta_{4}^{\Theta \cdot \operatorname{sign}\left(N_{5 c}\right)}+i_{4} \cdot M_{6 a}=0 \\
& M_{6 b}+M_{8 a}=0, Y=1 ; M_{7 b}=M_{8 b}=0, Y=1 \text {; } \\
& M_{5 d} \cdot \eta_{5}^{\Theta \cdot \operatorname{sign}\left(N_{5 d}\right)}+i_{5} \cdot M_{7 a}=0 \\
& M_{7 b}+M_{8 b}=0, Y=0 ; \quad M_{6 b}=M_{8 a}=0, Y=0 ; \\
& M_{8 c} \cdot \eta_{6}^{\Theta \cdot \operatorname{sign}\left(N_{8 c}\right)}+i_{6} \cdot M_{9 a}=0 ; \quad M_{8 d} \cdot \eta_{6}^{\Theta \cdot \operatorname{sign}\left(N_{8 d}\right)}+i_{6} \cdot M_{10 a}=0 ; \\
& M_{9 b}=M_{9 c}=M_{V 1} ; M_{10 b}=M_{10 c}=M_{V 2} ; \quad M_{0 a}+M_{0 b}=0 ; \quad M_{1 a}+M_{1 b}=0 ; \\
& M_{2 a}+M_{2 b}=0 ; \quad M_{20 a}+M_{20 b}=0 ; \\
& M_{3 a}+M_{3 b}=0 ; \quad M_{4 a}+M_{4 b}=0 ; \\
& M_{5 a}+M_{5 b}+M_{5 c}+M_{5 d}=0 ; \quad M_{6 a}+M_{6 b}=0 ; \quad M_{7 a}+M_{7 b}=0 ; \\
& M_{8 a}+M_{8 b}+M_{8 c}+M_{8 d}=0 ; \quad M_{9 a}+M_{9 b}+M_{9 c}+M_{9 d} \cdot \Omega=0 ; \\
& M_{10 a}+M_{10 b}+M_{10 c}+M_{10 d} \cdot \Omega=0 \text {, }
\end{aligned}
$$


where $\dot{\omega}_{i}$ is angular deceleration of a link; $\Psi$ is coefficient characterizing the type of motor-wheels connection in the process of mine diesel locomotive braking ( $\Psi=1$ is without kinematic disconnection; $\Psi=0$ is in terms of kinematic disconnection)); $e_{1}(t), e_{2}(t)$ are laws of changes in the parameters of HSD hydraulic machines control; $V_{0^{*}}$ is volume of compressible liquid; $E\left(g^{*}\right)$ is modulus of elasticity of operating liquid depending on $g^{*}$ gas content per cent; $\Delta P$ is operating pressure differential within HSD; $K_{i y}, C_{i y}$ are loss coefficients for a hydraulic pump $(i=1)$ and a hydraulic motor $(i=2) ; \mu$ is coefficient of dynamic viscosity; $Y$ is coefficient characterizing movement $(Y=1$ is traction movement, $Y=0$ is transport movement); $\eta_{j}$ is reducing gear efficiency; $\eta_{13}, \eta_{23}$ are efficiency within gear-tooth systems of sun-satellite gear epicycle-satellite gear in terms of stopped carrier determining moment losses; $\Theta$ is coefficient of loss recording within gear-tooth systems $(\Theta=0$ is without loss consideration, $\Theta=-1$ is loss consideration within gear-tooth systems); $N_{n m}$ is power transmitted by HSMT links; $\Delta M_{1}, \Delta M_{2}$ are losses of moments within hydraulic machines; $\bar{K}_{1}, \bar{K}_{2}, \ldots, \bar{K}_{8}$ are coefficients of hydromechanical losses; $D_{q i}$ is typical dimension of a hydraulic machine; $M_{\text {Vaxis }}$ are moments within the wheel axles which components are braking moments; axis are indices characterizing the number of axis (axis $=1$ is front axis, axis $=2$ is back axis); $\Omega$ is coefficients characterizing the state of braking mechanisms $(\Omega=1$ means that braking mechanisms are switched on; $\Omega=0$ means that braking mechanisms are switched off).

Two-dimensional mathematical model has been applied to analyze integrally braking processes of mine diesel locomotives with HSMT. Such a model makes it possible to obtain rather accurate qualitative description of braking dynamics of mine diesel locomotives in terms of action of comparatively low side forces. Moreover, it helps understand physics of the processes and determine effect of different factors on braking dynamics.

Braking process is modeled in terms of kinematic motor disconnection from wheels (further, the implementation technique will be specified as No. 1).

When a motor is disconnected from wheels in the process of a mine diesel locomotive deceleration, braking moments on wheels are $M_{9 d}$ and $M_{10 d}$. Since two-dimensional model is being considered rather than the three-dimensional one, then each of the abovementioned braking moments acts on axis but not on a wheel. $1 / 2$ of the common value falls within each axis wheel. Moreover, taking into consideration specifics of the applied approach to HSMT dynamics description, the modeling process should involve a sign of angular speed of a link experiencing the braking moment. Braking moment is always directed opposite to the braking link rotation effecting negative work [36].

In the process of braking, wheel angular speed is determined using the expressions:

$$
\begin{aligned}
& J_{1} \cdot \dot{\omega}_{9}=M_{x 1}-M_{f 1}-\left(M_{9 b}+M_{9 c}\right)=M_{x 1}-M_{f 1}-2 \cdot M_{V 1} ; \\
& J_{2} \cdot \dot{\omega}_{10}=M_{x 2}-M_{f 2}-\left(M_{10 b}+M_{10 c}\right)=M_{x 2}-M_{f 2}-2 \cdot M_{V 2},
\end{aligned}
$$

where $J_{\text {axis }}$ is inertia moments of rotating masses connected with axes; $\omega_{\text {axis }} *$ is angular speed of wheel axes (HSMT No. 1: $\left.\omega_{1^{*}}=\omega_{9}, \omega_{2^{*}}=\omega_{10}\right) ; M_{x a x i s}$ is moment developed by a response within longitudinal plane of axis wheels; $M_{\text {faxis }}$ is moment of resistance to wheel axis rolling [18].

A moment, developed by the response within the longitudinal plane of axis wheels, is

$$
M_{\text {xaxis }}=R_{\text {zaxis }} \cdot \varphi_{\text {axis }} \cdot r \text {, }
$$

where $R_{\text {zaxis }}$ is the total normal response within wheel axis of a mine diesel locomotive-rail contact; $\varphi_{\text {axis }}$ is wheel-rail adhesion coefficient.

Longitudinally, adhesion wheel characteristics are evaluated with the help of adhesion coefficient $[8-11,18]$ : 


$$
\varphi_{\text {axis }}=f\left(S_{\text {axis }}\right) \text {, }
$$

where $S_{\text {axis }}$ is relative skidding of wheel axis.

Since a two-dimensional model is considered, introduce such an assumption that during the whole braking process, wheel-rail adhesion coefficient of the right side of a mine diesel locomotive is equal to the wheel-rail adhesion of its left side.

Relative skidding of the wheel axis is identified using following expression:

$$
S_{\text {axis }}=\frac{V-\omega_{a x i s} \cdot r}{V},
$$

where $V$ is motion speed of a diesel locomotive.

During braking, angular wheel speed varies to be determined using following expression:

$$
\omega_{a x i s} * \omega_{a x i s * 0}-\omega_{a x i s} * \int_{0}^{t} \dot{\omega}_{a x i s *} d t,
$$

where $\omega_{a x i s^{*} 0}$ is initial value of angular wheel speed; $t$ is braking time.

Internal-combustion motor and description of a crank-shaft motion equation are integral parts of the abovementioned general mathematical model of the mine diesel locomotive brakeage. They are widely used in papers [45-47] since the model helps simulate several implementation techniques of the mine diesel locomotive brakeage inclusive of those characterized by preservation of kinematic wheel-motor connection. A general mathematical model of the brakeage process is supplemented by a model of internal-combustion motor as well as description of a crank-shaft motion equation from papers [46, 47]:

$$
J \cdot \dot{\omega}_{0}=\left(M_{n o r m}+\frac{\varepsilon_{r}-\varepsilon_{\omega}}{k_{x}-1}\right) \cdot M_{n o m}-M_{0 a},
$$

where $J$ is inertia moment normalized to a crank-shaft; $M_{\text {norm }}$ is standard torque of a motor; $\varepsilon_{r}$ is coefficient characterizing position of a member controlling fuel supply; $\varepsilon_{\omega}$ is coefficient of a motor loading in terms of rotational frequency; $k_{x}$ is coefficient to determined steepness of a regulatory branch of external speed characteristic; $M_{n o m}$ is nominal torque moment of a motor.

Mathematical model of a diesel motor in dimensionless values is easy to use taking into consideration its loading and fuel supply since only the data, listed in the motor specification, are needed as the initial parameters. As for the adequacy, it has been tested repeatedly and proved in papers $[9,11,36,43-47]$ for acceleration of self-propelled machines and for their brakeage.

The approach to the description of effect of external forces on a mine diesel locomotive and features of wheel-bearing surface (rail) interaction, used in this context, has been known since the 1970s research, is quite popular to describe dynamics of self-propelled equipment $[11,18,20,36]$.

The abovementioned model of a brakeage process $(1-11)$ will be efficient if only $\varphi_{\text {axis }}=f\left(S_{\text {axis }}\right)$ dependence is determined.

More accurate formalized presentation of adhesion characteristic in terms of the developed mathematical model should involve experiments concerning interaction of such frictional pair as wheel-rail with the intervening medium availability, and use of modern techniques for data recording and processing. That will help improve braking potential of a diesel locomotive owing to more efficient use of diesel output and adhesive weight.

Paper [48] represents experimental dependences of the adhesion coefficient upon relative skidding in terms of different conditions of a rail surface (Fig. 3); however, their mathematical description is not available. 


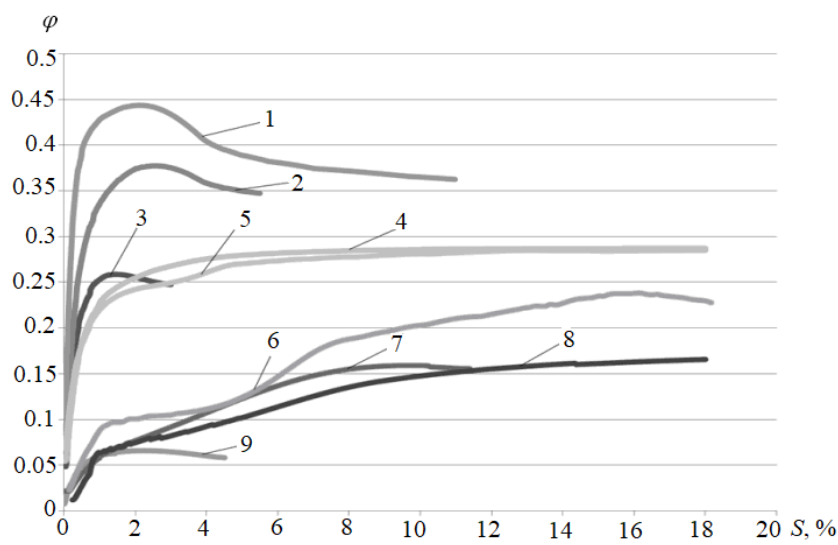

Fig. 3. Experimental dependences of adhesion coefficient upon relative skidding in terms of different frictional conditions of a rail surface [48]: 1 - rails are covered with a thin layer of coal dust; 2 - rails are covered with a thin layer of rock dust; 3 - rails are clean and dry; 4 - rails are covered with a thick layer of rock dust; 5 - rails are covered with a thick layer of coal dust; 6 - rails are submerged; 7 rails are covered with a wet coal-rock mixture; 8 - rails are covered with a watered coal-rock mixture; 9 - rails are covered with motor oil.

Scientific sources [49] recognize approximating functions to describe $\varphi-S$ diagrams. The proposed models by Pacejka (known as a "magic formula"), Burckhardt, Wei-En Ting, and Jung-Shan Lin $[50,51]$ recommend identifying a theoretical dependence, approaching maximally experimental one for various road conditions, while diversifying different coefficients.

Since relative skidding varies rather broadly (exceeding 10\%) in the brakeage process, then dependence 4 from Fig. 3 is the most appropriate to be used while braking modeling as it is characterized by maximum values of adhesion coefficient to compare with other dependences. Moreover, it is quite sufficient to simulate a pattern of $\varphi$ variation.

Assume a mathematical description of adhesion coefficient variance from relative skidding in terms of "a rail is covered with a thick layer of rock dust" as (Fig. 4):

$$
\varphi(S)=\left[C_{1} \cdot\left(1-C_{2}{ }^{-C_{3} \cdot S}\right)-C_{4} \cdot S\right] \cdot C_{2}{ }^{C_{5} \cdot S \cdot C_{6}},
$$

where $C_{1}, \ldots, C_{6}$ is coefficients determined theoretically: $C_{1}=0.28, C_{2}=3.74, C_{3}=83.708$, $C_{4}=0.1204, C_{5}=0.04, C_{6}=10.0$.

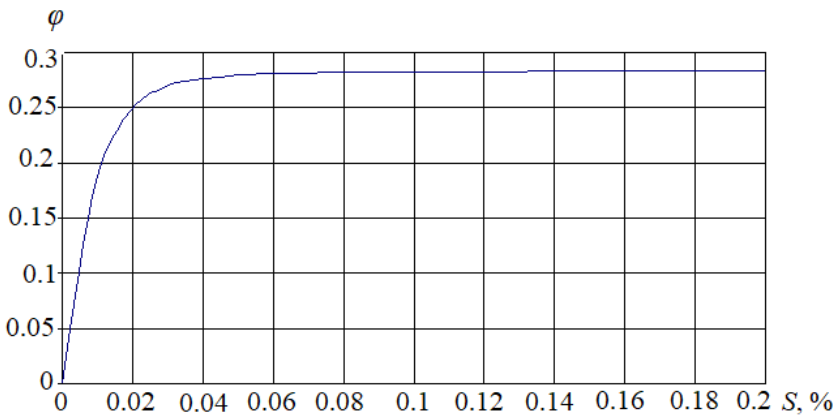

Fig. 4. Theoretical dependence of adhesion coefficient upon relative skidding in terms of "a rail is covered with a thick layer of rock dust". 
Theoretical dependence of adhesion coefficient upon relative skidding in terms of "a rail is covered with a thick layer of rock dust" (Fig. 4) has $98 \%$ match with experimental dependence No. 4 in Fig. 3.

\section{Modeling results}

Distribution of kinematic parameters, power parameters, and energy parameters of HSMT in the braking process depends heavily on:

- Transmission type;

- Initial speed (diesel locomotive braking process starts from the velocities of $V_{\max }$ and $0.5 V_{\max }$, in terms of HSMT No. $1 V_{\max }$ within transport range is $20.24 \mathrm{~km} / \mathrm{h}$; within traction range it is $10.02 \mathrm{~km} / \mathrm{h}$ );

- Drawbar force (as a rule, in terms of movement within transport range, mine cars are empty, their maximum number is $\mathrm{n}$ for the selected operating conditions that is equivalent to 2 loaded mine cars (it is assumed with ample); in terms of traction range, two loading variants are considered: 8 or 2 loaded mine cars);

- Ascending and descending angle (being equivalent to $50 \%$ );

- Method of braking process. As it has been mentioned, a braking process is modeled under the conditions of kinematic motor disconnection from wheels in terms of maximum possible braking moments on wheels as well as two different laws of $e_{1}(t)$ and $e_{2}(t)$ variation. $e_{1}(t)$ and $e_{2}(t)$ law one will be characterized by changes in control parameters of HSD hydraulic machines according to the changes in actual motion speed of a mine diesel locomotive being specified as $e_{1} \_\mathrm{Vcur}(t)$ and $e_{2} 1 \mathrm{Vcur}(t)$. In the context of law 2, HSD control parameters remain constant during the whole braking process; they correspond to the value they had at the braking start, i.e. $e 1_{-} 1 \mathrm{Vmax}(t)$ and $e_{2}{ }_{1 \mathrm{~V} \max }(t)$. Since torque moments on the transmission links are equal to zero within areas of interruption in torque delivery, the motor will not be able to affect significantly the braking process dynamics.

From the viewpoint of the braking process dynamics, theoretical substantiation of the promising HSMT is possible owing to the software support developed with the help of MatLab/Simulink. Fig. 5 explains its structure.

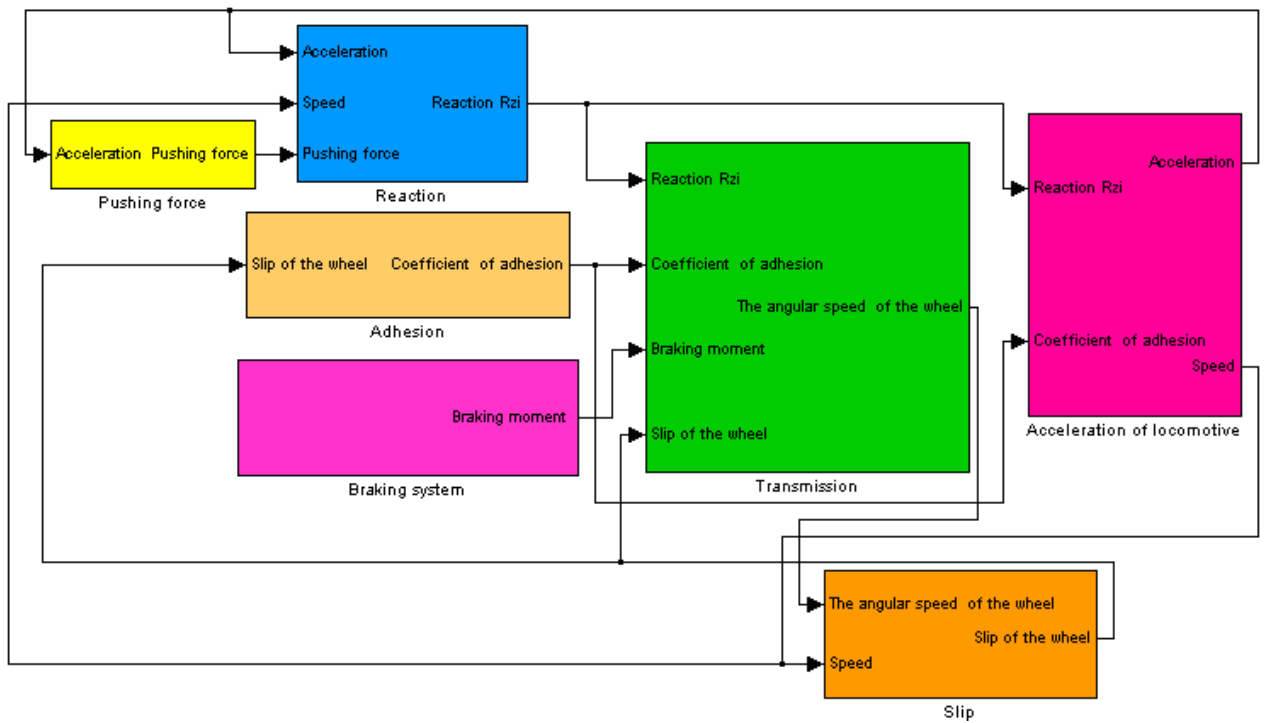

Fig. 5. External view of the software support to implement braking process of a mine diesel locomotive. 
Angular velocities of transmission links and working pressure differential in HSD for HSMT No. 1 had following initial values:

- within the transport range:

$-V=20.24 \mathrm{~km} / \mathrm{h}, \omega_{1}=210.0 \mathrm{rad} / \mathrm{s}, \omega_{2}=-61.2 \mathrm{rad} / \mathrm{s}, \omega_{3}=102.9 \mathrm{rad} / \mathrm{s}, \Delta P=11.85 \mathrm{MPa}$, $e_{1}=1, e_{2}=0.5$;

$-V=10.12 \mathrm{~km} / \mathrm{h}, \omega_{1}=210.0 \mathrm{rad} / \mathrm{s}, \omega_{2}=-200.5 \mathrm{rad} / \mathrm{s}, \omega_{3}=51.36 \mathrm{rad} / \mathrm{s}, \Delta P=19.6 \mathrm{MPa}$, $e_{1}=0.36, e_{2}=1$;

- within the tractive range:

$-V=10.02 \mathrm{~km} / \mathrm{h}, \omega_{1}=210.0 \mathrm{rad} / \mathrm{s}, \omega_{2}=-53.3 \mathrm{rad} / \mathrm{s}, \omega_{3}=105.8 \mathrm{rad} / \mathrm{s}, \Delta P=13.55 \mathrm{MPa}$, $e_{1}=1, e_{2}=0.4$

$-V=5.01 \mathrm{~km} / \mathrm{h}, \omega_{1}=210.0 \mathrm{rad} / \mathrm{s}, \omega_{2}=-195.9 \mathrm{rad} / \mathrm{s}, \omega_{3}=53.05 \mathrm{rad} / \mathrm{s}, \Delta P=21.0 \mathrm{MPa}$, $e_{1}=0.384, e_{2}=1$.

Following parameters are studied in the process of braking modeling:

- Maximum value of working pressure differential in HSD $|\Delta P|_{\max }$ which should not be more than the $40.0 \mathrm{MPa}$ for hydraulic machines with the working volume of $90 \mathrm{~cm}^{3}$;

- Maximum value of angular speed of a hydraulic pump shaft $\left|\omega_{2}\right|_{\max }$ should not be more than $460.0 \mathrm{rad} / \mathrm{s}$;

- Maximum value of angular speed of a hydraulic motor shaft $\left|\omega_{3}\right|_{\max }$ should not be more than $460.0 \mathrm{rad} / \mathrm{s}$;

- Maximum value of output power by a hydraulic branch of the closed circuit of HSMT power output should be $\left|N_{g k}\right|_{\max }$;

- Maximum value of output power by a mechanical branch of closed circuit of HSMT power output should be $\left|N_{m k}\right|_{\max }$ (Preliminary identification of the power values is impossible since due to origination of the power circulation, more potential energy may be transferred through a hydraulic branch or a mechanical one being even higher than the motor power. Theoretically, the total of the two powers should not exceed the motor output (ignoring its coefficient of efficiency));

- Braking path is $S$;

- Braking period is $t$.

Table 1 demonstrates the results of the comprehensive analysis of a braking process of a mine diesel locomotive with HSMT No. 1 at the expense of HSD and brakes in the context of kinematic disconnection of a motor from wheels. Fig. 6 visualizes the modeling results.

Table 1. The results of the comprehensive analysis of a braking process.

\begin{tabular}{|l|c|c|c|c|}
\hline \multicolumn{1}{|c|}{ Index } & \multicolumn{2}{c|}{ Transportation mode } & \multicolumn{2}{c|}{ Tractive mode } \\
\hline Initial braking speed, $\mathrm{km} / \mathrm{h}$ & 20.24 & 10.12 & 10.02 & 5.01 \\
\hline \multicolumn{5}{|c|}{ Rails are covered with a thick layer of rock dust } \\
\hline Braking path, $\mathrm{m}$ & 24.7 & 14.1 & 34.6 & 21.8 \\
\hline Braking period, $\mathrm{s}$ & 17.2 & 10.7 & 15.7 & 13.6 \\
\hline \multicolumn{5}{|c|}{ Rails are covered with a thin layer of coal dust } \\
\hline Braking path, $\mathrm{m}$ & 31.2 & 16.8 & 42.6 & 30.8 \\
\hline Braking period, $\mathrm{s}$ & 20.6 & 12.8 & 18.8 & 16.3 \\
\hline \multicolumn{7}{|c|}{ Rails are covered with wet coal dust } \\
\hline Braking path, $\mathrm{m}$ & 39.8 & 22.7 & 55.7 & 35.1 \\
\hline Braking period, $\mathrm{s}$ & 27.7 & 17.2 & 25.3 & 21.9 \\
\hline
\end{tabular}

Despite the fact that working pressure difference $\Delta P$ within a HSD is assumed as the initial condition in a mathematical model of a braking process, the software support specifies it immediately in accordance with the operating conditions taking into consideration a technique of the braking process implementation. That is why $\Delta \mathrm{P}$ values, 
assumed as the initial one, will differ from a value obtained in the process of a braking modeling. Concerning other parameters, the values, assumed as the initial one, will correspond to the first values obtained in the process of brakeage modeling.
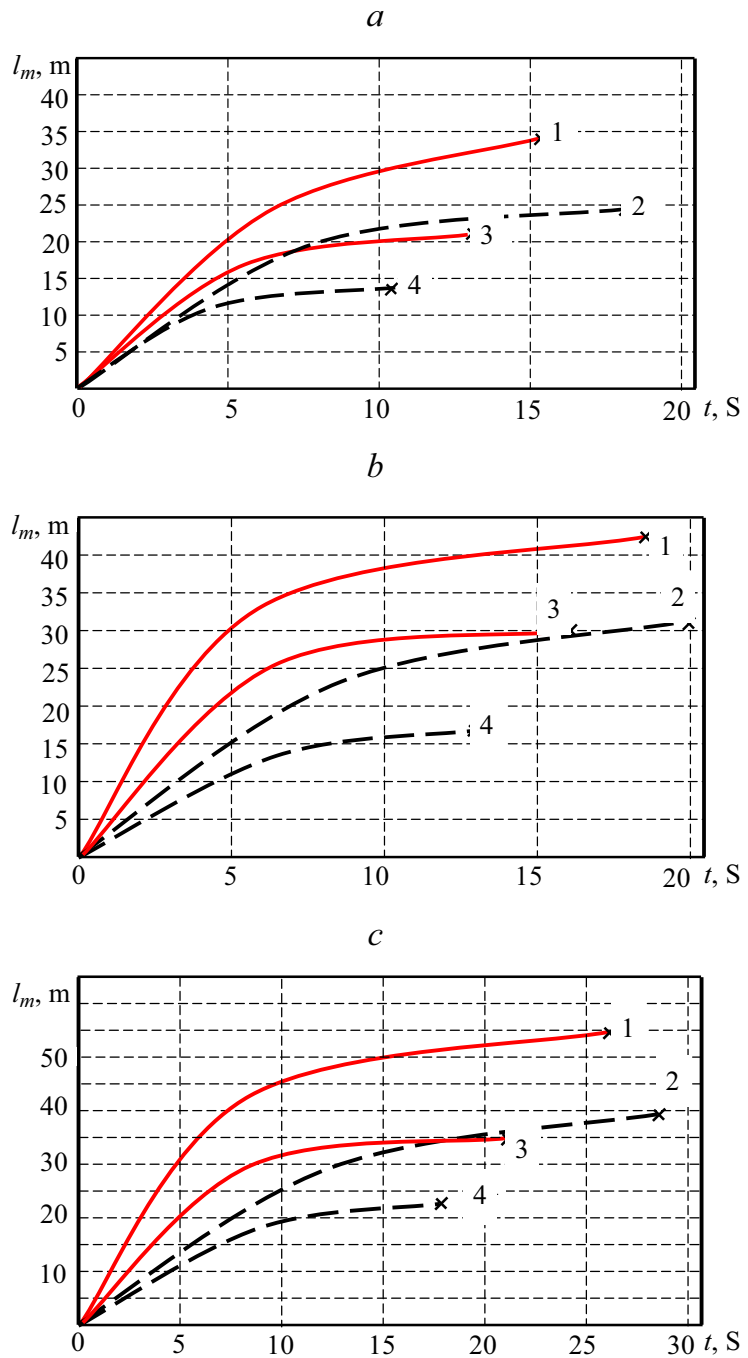

Fig. 6. The modeling results concerning braking process of a mine diesel locomotive under different conditions of rails: $\mathrm{a}$ - rails are covered with a thick layer of rock dust; $b$ - rails are covered with a thin layer of coal dust; $\mathrm{c}$ - rails are covered with wet coal dust; curve 1 - tractive mode, $V_{0}=10.02 \mathrm{~km} / \mathrm{h}$; curve 2 - transportation mode, $V_{0}=20.24 \mathrm{~km} / \mathrm{h}$; curve 3 - tractive mode, $V_{0}=5.01 \mathrm{~km} / \mathrm{h}$; curve 4 - transportation mode, $V_{0}=10.12 \mathrm{~km} / \mathrm{h}$.

At the expense of kinematic disconnection of a mechanical branch of the closed HSMT loop, tractive effort within a mine diesel locomotive hook cannot have a major effect on the distribution of kinematic, power, energy HSMT parameters; their divergence is not more than $0.81 \%$. As for the ascending/descending angle influence, discrepancy in $|\mathrm{dP}|_{\max }$, $\left|w_{20}\right|_{\max },\left|w_{2}\right|_{\max },\left|w_{3}\right|_{\max }$, and $\left|N_{\mathrm{gk}}\right|_{\max }$ values is not more than $4.5 \%$. 
When decrease in the initial brakeage speed takes place, only a value of a working pressure difference within HSD increases as well as angular speed of a hydraulic pump shaft of HSMT No. 1.

While a mine diesel locomotive with HSMT No. 1 braking at the expense of HSD and brakes in terms of kinematic disconnection of a motor on rails, covered with a thick layer of rock dust, braking path is $24.7 \mathrm{~m}$ in terms of transportation mode and $20.24 \mathrm{~km} / \mathrm{h}$ initial speed. If the initial speed falls by half (i.e. down to $10.12 \mathrm{~km} / \mathrm{h}$ ) then braking path is $4.1 \mathrm{~m}$ (i.e. by $42 \%$ ). Similar speed decrease in a tractive mode results in the braking path decrease from 34.6 down to 21.8 (i.e. by $36 \%$ ). Twofold speed decrease in terms of other analyzed rail conditions also results in the decreased absolute value of a braking path; however, relative decrease for rails, covered with a thin layer of coal dust, is $49 \%$ for transportation mode and $47 \%$ for tractive mode.

\section{Conclusions}

Qualitative evaluation has been performed as for the initial braking speed as well as tractive force of a mine diesel locomotive influence on the distribution of kinematic, power, and energy parameters within HSMT. Basic regularities of the distribution of power flows within the closed loop of "input differential" HSMT in the process of a mine diesel locomotive braking have been identified and systemized. Since kinematic disconnection of a mechanical branch takes place within the closed loop of HSMT No. 1 at the expense of a clutch, neither ascent/descent angle nor tractive effort within a mine diesel locomotive hook effect significantly the distribution of kinematic, power, and energy parameters of the HSMT.

Analysis of the modeling results supports significant dependence of the braking process parameters upon a type and condition of intervening medium within the wheel-rail contact area confirming the statement by A.A. Rengevich that "nature of rail contamination is the determinative factor for an adhesion coefficient value...".

At the same time, comparison of the modeling results with those, represented in papers $[9,38]$, has shown that brakeage of a mine diesel locomotive with HSMT No. 1 at the expense of HSD and brakes in terms of kinematic disconnection of a motor differs slightly from the experimental values (the discrepancy is $18 \%$ for brakeage in terms of rails, covered with a thin layer of coal dust up to $26 \%$ in terms of rails covered with wet coal dust). The discrepancy may depend upon certain differences in the experimentation methods and conditions. However, we believe that possible reason is a transmission itself having no rigid connection with a wheel. Nevertheless, the hypothesis needs theoretical research and experiments.

The team of authors expresses deep appreciation to Vadym Borysovych Samorodov, Professor, Doctor of Technical Sciences, Head of the Department of Automobile and Tractor Construction of the National Technical University "Kharkiv Polytechnic Institute" for his support, and valuable remarks at all stages of the research execution.

\section{References}

1. Sładkowski, A., Utegenova, A., Kolga, A.D., Gavrishev, S.E., Stolpovskikh, I., \& Taran, I. (2019). Improving the efficiency of using dump trucks under conditions of career at open mining works. Naukovyi Visnyk Natsionalnoho Hirnychoho Universytetu, (2), 36-42. https://doi.org/10.29202/nvngu/2019-2/8

2. Zabolotny, K., \& Panchenko, E. (2010). Definition of rating loading in spires of multilayer winding of rubberrope cable. New Techniques and Technologies in Mining - Proceedings of the 
School of Underground Mining, 223-229. https://doi.org/10.1201/b11329-38

3. Larsson, L.V., Larsson, K.V. (2014). Simulation and Testing of Energy Efficient Hydromechanical Drivelines for Construction Machinery. Master's Thesis (p. 126). Linköping, Sweden: Linköping University.

4. Taran, I., \& Klymenko, I. (2014). Innovative mathematical tools for benchmarking transmissions of transport vehicles. Naukovyi Visnyk Natsionalnoho Hirnychoho Universytetu, (3), 76-81.

5. Anderl, T., Winkelhake, J., \& Scherer, M. (2012). Power-split transmissions for construction machinery. In Proceedings of the 8th International Fluid Power Conference (pp. 189-201). Dresden, Germany.

6. Macor, A., \& Rossetti, A. (2011). Optimization of hydro-mechanical power split transmissions. Mechanism and Machine Theory, 46(12), 1901-1919. https://doi.org/10.1016/j.mechmachtheory.2011.07.007

7. Pivnyak, G., Bondarenko, V., \& Kovalevska, I. (Eds.). (2015). New Developments in Mining Engineering 2015. London, United Kingdom: CRC Press, Taylor \& Francis Group. https://doi.org/10.1201/b19901

8. Taran, I., \& Bondarenko, A. (2017). Conceptual approach to select parameters of hydrostatic and mechanical transmissions for wheel tractors designed for agrucultural opeations. Archives of Transport, 4l(1), 89-100. http://doi.org/10.5604/01.3001.0009.7389

9. Samorodov, V., \& Pelipenko E. (2016). Analysis of the development modern transmission wheeled tractors. Wspótpraca Europejska, (6), 49-57.

10. Pivnyak, G., Bondarenko, V., Kovalevs'ka, I., \& Illiashov, M. (2012). Geomechanical Processes During Underground Mining, 238 p. Book. https://doi.org/10.1201/b13157

11. Samorodov, V., Taran, I., Bondarenko, A., \& Klymenko, I. (2019). Comparative analysis of transmissions of mine diesel locomotive with different component schemes. Naukovyi Visnyk Natsionalnoho Hirnychoho Universytetu, (5), 87-92. https://doi.org/10.29202/nvngu/2019-5

12. Gornostayev, S.S., Crocket, J.H., Mochalov, A.G., \& Laajoki, K.V.O. (1999). The platinumgroup minerals of the Baimka placer deposits, Aluchin horst, Russian Far East. Canadian Mineralogist, 37(5), 1117-1129.

13. Chernai, A.V., Sobolev, V.V., Chernai, V.A., Ilyushin, M.A., \& Dlugashek, A. (2003). Laser ignition of explosive compositions based on di-(3-hydrazino-4-amino-1,2,3-triazole)-copper(II) perchlorate. Combustion, Explosion and Shock Waves, 39(3), 335-339. https://doi.org/10.1023/A:1023852505414

14. Shashenko, A., Gapieiev, S., Solodyankin, A. (2009). Numerical simulation of the elastic-plastic state of rock mass around horizontal workings. Archives of Mining Sciences, 54(2), 341-348.

15. Sobolev, V. V., \& Usherenko, S. M. (2006). Shock-wave initiation of nuclear transmutation of chemical elements. Journal de Physique IV (Proceedings), (134), 977-982. https://doi.org/10.1051/jp4:2006134149

16. Mikhlin, Y. V., \& Zhupiev, A. L. (1997). An application of the ince algebraization to the stability of non-linear normal vibration modes. International Journal of Non-Linear Mechanics, 32(2), 393-409. https://doi.org/10.1016/s0020-7462(96)00047-9

17. Litvinova, Ya., Nosal-Hoy, K., Solecka, K., \& Taran, I. (2020). Improvement of efficiency of processes of mining product processing at transport hubs. Naukovyi Visnyk Natsionalnoho Hirnychoho Universytetu, (1), 141-145. https://doi.org/10.33271/nvngu/2020-1/141

18. Protsiv, V., Novytskyi, O., \& Samoilov, A. (2012). Advantages of magnetic loader over rail brakes on mine locomotive. Naukovyi Visnyk Natsionalnoho Hirnychoho Universytetu, (4), 79-83.

19. Singh, R.B., Kumar, R., \& Das, J. (2013). Hydrostatic transmission systems in heavy machinery: overview. International Journal of Mechanical and Production Motorering, 1(4), 47-51.

20. Matsyuk, I., \& Shlyahov, E. (2015). The research of plane link complex-structure mechanisms by vector algebra methods. Eastern-European Journal of Enterprise Technologies, 3(7(75)), 34. https://doi.org/10.15587/1729-4061.2015.44236 
21. Taran, I. (2012). Interrelation of circular transfer ratio of double-split transmissions with regulation characteristic in case of planetary gear output. Naukovyi Visnyk Natsionalnoho Hirnychoho Universytetu, (3), 75-85.

22. Rydberg, K. (2010). Hydro-mechanical Transmissions. Fluid and Mechatronic Systems, (2), 51-60.

23. Karbaschian, M., \& Söffker, D. (2014). Review and Comparison of Power Management Approaches for Hybrid Vehicles with Focus on Hydraulic Drives. Energies, 7(6), 3512-3536. https://doi.org/10.3390/en7063512

24. Tikkanen, S, Hurtala, K, Vilenius, M. (1997). Design aspects of tractive control in hydrostatic power transmissions. In The First Scandinavian International Conference on Fluid Power. Linkohing, Sweden.

25. Erikkilä, M. (2009). Model-based Design of Power-Split Drivelines. PhD Thesis. Tampere, Finland: Tampere University of Technology.

26. Hu, J., Wei, C., Yuan, S., \& Jing, C. (2009). Characteristics on Hydro-mechanical Transmission in Power Shift Process. Chinese Journal of Mechanical Engineering, 22(01), 50. https://doi.org/10.3901/cjme.2009.01.050

27. Cheong, K., Li, P., \& Chase, T. (2011). Optimal design of power-split transmissions for hydraulic hybrid passenger vehicles. In Proceedings of the 2011 American Control Conference (pp. 32953300). San Francisco, USA. https://doi.org/10.1109/acc.2011.5991509

28. Nilsson, T., Fröberg, A., \& Åslund, J. (2012). Fuel potential and prediction sensitivity of a powersplit CVT in a wheel loader. IFAC Proceedings, 45(30), 49-56. https://doi.org/10.3182/201210233-fr-4025.00017

29. Liu, X., Sun, D., Qin, D., \& Liu, J. (2017). Achievement of Fuel Savings in Wheel Loader by Applying Hydrodynamic Mechanical Power Split Transmissions. Energies, 10(9), 1267. https://doi.org/10.3390/en10091267

30. Comellas, M., Pijuan, J., Potau, X., Nogués, M., \& Roca, J. (2013). Efficiency sensitivity analysis of a hydrostatic transmission for an off-road multiple axle vehicle. International Journal of Automotive Technology, 14(1), 151-161. https://doi.org/10.1007/s12239-013-0017-z

31. Schulte, H. (2007). Control-oriented Modeling of Hydrostatic Transmissions Considering Leakage Losses. IFAC Proceedings, 40(21), 103-108. https://doi.org/10.3182/20071029-2-fr$\underline{4913.00018}$

32. Macor, A., \& Rossetti, A. (2013). Fuel consumption reduction in urban buses by using power split transmissions. Energy Conversion and Management, (71), 159-171. https://doi.org/10.1016/j.enconman.2013.03.019

33. Kim, H., Oh, K., Ko, K., Kim, P., \& Yi, K. (2016). Modeling, validation and energy flow analysis of a wheel loader. Journal of Mechanical Science and Technology, 30(2), 603-610. https://doi.org/10.1007/s12206-016-0114-9

34. Zhang, H., Liu, F., Zhu, S., Xiao, M., Wang, G., Wang, G., \& Zhang, W. (2016). The optimization design of a new type of hydraulic power-split continuously variable transmission for high-power tractor. Journal of Nanjing Agricultural University, (39), 156-165.

35. Taran, I.A. (2012). Laws of power transmission on branches of double-split hydrostatic mechanical transmissions. Naukovyi Visnyk Natsionalnoho Hirnychoho Universytetu, (2), 69-75.

36. Novytskyi, O., Taran, I., \& Zhanbirov, Z. (2019). Increasing mine train mass by means of improved efficiency of service braking. E3S Web of Conferences, (123), 01034. https://doi.org/10.1051/e3sconf/201912301034

37. Taran, I., Klymenko, I. (2013). Transfer ratio of double-split transmissions in case of planetary gear input. Naukovyi Visnyk Natsionalnoho Hirnychoho Universytetu, (6), 60-66.

38. Gruhler, G., Bublikov, A., Gorlach, I., \& Cawood, G. (2015). Control strategy for a mobile platform with an omni-directional drive. Naukovyi Visnyk Natsionalnoho Hirnychoho Universytetu, (2), 84-90.

39. Deryugin, O., \& Cheberyachko, S. (2015). Substatiation of truck selection in terms of psychophysiologic stress on a driver minimizing. Eastern-European Journal of Enterprise 
Technologies, (3(3(75)), 15-22. https://doi.org/10.15587/1729-4061.2015.42127

40. Pettersson, K. (2013) Design Automation of Complex Hydromechanical Transmissions. Linköping Studies in Science and Technology. Thesis, (1620), 458-467. https://doi.org/10.3384/lic.diva-99382

41. Taran, I., \& Klymenko, I. (2017). Analysis of hydrostatic mechanical transmission efficiency in the process of wheeled vehicle braking. Transport Problems, 12(SE), 45-56. https://doi.org/10.20858/tp.2017.12.se.4

42. Samorodov, V.B. (1999). Vyvod kinematicheskikh bazisnykh matrits i sistemnyy analiz kinematiki stupenchatykh mekhanicheskikh i gidroob'yomno-mekhanicheskikh trasmissiy. Sbornik Nauchnykh Trudov KhGPU, (7), 363-370.

43. Samorodov, V., Kozhushko, A., \& Pelipenko, E. (2016). Formation of a rational change in controlling continuously variable transmission at the stages of a tractor's acceleration and braking. Eastern-European Journal of Enterprise Technologies, 4(7(82)), 37-44. https://doi.org/10.15587/1729-4061.2016.75402

44. Samorodov, V.B., \& Bondarenko, A.I. (2012). Tendentsii ta perspektyvy zastosuvannia v avtomobile- i traktorobuduvanni bezstupinchastykh hidroobiemno-mekhanichnykh transmisii. Avtomobilnyi transport, (30), 13-22.

45. Beshta, O.S. (2012). Electric drives adjustment for improvement of energy efficiency of technological processes. Naukovyi Visnyk Natsionalnoho Hirnychoho Universytetu, (4), 98-107.

46. Carl, B., Ivantysynova, M., \& Williams, K. (2006). Comparison of Operational Characteristics in Power Split Continuously Variable Transmissions. SAE Technical Paper Series. https://doi.org/10.4271/2006-01-3468

47. Rebrov, A.Y., Korobka, T.A., \& Lakhman, S.V. (2012). Matematicheskaya model' dizel'nogo dvigatelya $\mathrm{v}$ bezrazmernykh velichinakh $\mathrm{s}$ uchetom yego zagruzki i podachi topliva. Visnyk Natsionalnoho Tekhnichnoho Universytetu "KhPI", (19), 31-36.

48. Kostyukevich, A.I., Taran, I.A., Kovtanets, M.V., \& Nozhenko, V.S. (2011). Eksperimentalnye issledovaniya kharakteristik stsepleniya v kontakte "koleso-rels" pri nalichii promezhutochnoy sredy. Visnyk Natsionalnoho Tekhnichnoho Universytetu "KhPI". Tematychnyi vypusk: Avtomobile- $i$ traktorobuduvannia, (56), 56-62.

49. Bondarenko, A.I. (2008). Vybor i obosnovanie approksimiruyushchey funktsii $\varphi-S$ diagrammy. Uchenye Zapisi Krymskogo Inzhenerno-Pedagogicheskogo Universiteta, (16), 95-98.

50. Pacejka, H., Sharp R.S. (2007). Shear Force Development by Pneumatic Tyres in Steady State Conditions: A Review of Modelling Aspects. Vehicle System Dynamics, 20(3-4), 121-175. https://doi.org/10.1080/00423119108968983

51. Burckhardt, M. (1984). Antiblochiersysteme im Vergleich. Olhydraul Und Pneum, (28), 489-491. 